\title{
ORGANIZATIONAL PSYCHOLOGY
}

\section{The Impact of Organizational and Personal Factors on Procrastination in Employees of a Modern Russian Industrial Enterprise}

\author{
Valentina V. Barabanshchikova, Svetlana A. Ivanova*, Oksana A. Klimova \\ Faculty of Psychology, Lomonosov Moscow State University, Moscow, Russia \\ *Corresponding author: ivanova_lana1986@rambler.ru
}

Background. This article addresses the influence of personal, professional, and organizational factors on procrastination in employees of a modern Russian industrial enterprise. Procrastination has been studied extensively since the 1970s, producing great research material and diagnostic tools that remain relevant to this day. Yet despite the large number of studies, no single point of view has emerged on the causes of this phenomenon.

Aim. To investigate how personal, professional, and organizational factors influence procrastination in employees of a modern Russian industrial enterprise.

Design. 120 employees of a Russian industrial enterprise participated in the study, including 70 women and 50 men, mean age 35 years, mean work experience in this enterprise 4.3 years. We used four diagnostic methods to characterize work activity and organizational culture, personal characteristics, and specificity of an occupational stress syndrome. We used correlation and regression analysis to analyze the results.

Results. The data identified significant personal, professional, and organizational predictors of procrastination in the modern professional, such as being outgoing (the quality of sociability), innovative, detail-conscious, and conscientious. Equally significant are characteristics of the work situation such as its content and the significance of tasks. A significant weight in the predictive value of the regression model lies in the robust consequences of professional stress (anxiety and depression), openness toward change in the organization, and social desirability.

Conclusion. The level of procrastination among the employees of this enterprise predicts typical behavior patterns in performing professional tasks, subjective appraisal of the job situation, the experience of stress and its consequences, and perception of the organizational culture.

Keywords: procrastination, predictors of procrastination, typical behavior patterns in occupational situations, occupational stress syndrome, stress consequences, work environment, organizational culture. 


\section{Introduction}

"Never put off 'till tomorrow what can be done today" - this statement by Benjamin Franklin has become a proverb, reflecting one of the characteristics of human nature - "to put away for later" seemingly urgent matters. Everyone is familiar with the urge to postpone doing a responsible task or making an important decision, but there are people for whom such procrastination becomes a lifetime habit. In psychology this phenomenon is called "procrastination" and people who have such tendency, are called "procrastinators" (Kovylin, 2013; Mohova, \& Nevrjueev, 2013; Varvaricheva, 2013). The word "procrastination" has a Latin origin and consists of the prefix "pro", which means moving forward, and "crastinus", which means tomorrow. In Russian, the term is frequently used in its English form, but there are separate scientists insist on using a Russian phrase, e.g., "putting something away for later" (Tarasevich, 2014).

The word "procrastination" has a rich history of use in Latin and English. The Romans used the word to describe putting off a battle decision in order to demonstrate restraint in a military conflict. The Oxford English Dictionary cites the use of this word in a manuscript from 1548, in the meaning of an "informed delay", "wisely chosen restraint" (Ferrari, Johnson, \& McCown, 1995, p. 4). Starting with the Industrial Revolution in the 19th century, the term began to appear in the literature with the stress more frequently on the negative connotation. Some scientists, for example, Milgram, Gehrman, and Keinan (1992), maintain that a negative attitude towards procrastination appeared in industrially developed countries at the same time as the emergence of new social values such as orientation to results, speed of reaction to change, and the importance of being accurate and punctual, along with the increasing tempo of life, when the synonym of success in life became the urge to keep up with constantly accelerating technical progress, even at the cost of one's own health (Kuper \& Marshall, 2009). This point of view is controversial, because some scientists acknowledge that procrastination has existed since the emergence of human society, finding confirmation of this in the works of ancient Greek and Egyptian philosophers (Steel, 2007).

One of the first uses of the term procrastination in a scientific context was thought to be in a book written by P. Ringenbach in 1971, but, according to Aitken (1982), the work was actually never written (Steel, 2007). The term began to occur in scientific studies, peaking in the 1980s, when the first studies were conducted and a number of measurement instruments were created. The best-known are the Tel-Aviv Procrastination Inventory by Milgram (TAP), the Procrastination Assessment Scale for Students by L. Solomon and E. Rothblum (PASS), the General Procrastination Scale by C. Lay (GP), the Aitken Procrastination Inventory (API), and the Tuckman General Procrastination Scale (TGPS). Some of the methods developed at that time are still being used by scientists.

One of the first scientists to systematically study procrastination was N. Milgram (Milgram et al., 1992). He identified four essential components of procrastination: (a) a behavioral sequence of postponement, resulting in (b) a substandard behavioral product, involving (c) a task that is perceived by the procrastinator as being important to perform, and resulting in (d) a deteriorating emotional state (Ferrari, Johnson, \& McCown, 1995). Since the first publication of Milgram's 
works, procrastination has been quite a popular topic of Western studies; on the other hand, there are still many controversial points of view about the phenomenon, which fuels the interest in its further exploration.

Ferrari summarizes a number of studies and proposes to separate the concepts of functional and dysfunctional procrastination (Ferrari, Johnson, \& McCown, 1995), dividing all of the studies into two groups. The first group explores procrastination in its constructive aspect, e.g., as a conscious delay in performing the task to a more optimal time, in order to increase the probability of success; as a kind of productive coping strategy (Krjukova, 2010; Shemjakina, 2013); as a conscious putting off "for later" in order to evoke intense feelings, which partly corresponds to the concept of "agitated" procrastinators. From this perspective, procrastination is considered a deliberate strategy, which often does not have a negative impact on the result, but, on contrary, allows a person to concentrate for the final plunge, and is accompanied by positive emotions. A second group of researchers consider procrastination as a dysfunctional phenomenon, a self-destructive behavior (Burka \& Yuen, 2008) and protective mechanism (Steel, 2007), which corresponds to the concept of "avoiding" procrastinators. Both approaches are legitimate and have a number of scientific confirmations, but there is a certain doubt about whether these works are addressing the same phenomenon. Currently there is an opinion that various scientists are studying somewhat different constructs, which are generalized in one term "procrastination" (Barabanshchikova, 2016). Many studies in the field of procrastination address the effort to establish why people, while being aware of the urgency, importance, and necessity of doing a task, postpone it, often with a negative impact on the final result.

Mokhova and Nevryuev (2013) propose to divide all studies on this topic into two groups: those that study internal reasons for procrastination and those that study external ones. Internal psychological reasons or individual personality factors (Varvaricheva, 2013) in procrastination are a person's predispositions, which are based on a number of personality traits, characteristics, and states. A number of studies have confirmed a connection between procrastination and perfectionism, anxiety, the Big Five factors, motivation characteristics (including the skill of selfmotivation), stress, etc. (Barabanshchikova, 2016; Dementij \& Karlovskaja, 2013; Ferrari \& Emmons, 1995; Garanjan, Andrusenko, \& Hlomov, 2009; Karlovskaja, 2008; Milgram \& Tenne, 2000; Shemjakina, 2013; Steel, 2007; Vindeker \& Ostanina, 2014; Zvereva, 2015; Zvereva, Enikolopov, \& Olejchik, 2015). External or situational predictors of procrastination (Varvaricheva, 2013) are mainly considered to be the characteristics of the tasks themselves. There are studies that have explored the influence of the type of task, the extent of the task's aversiveness, the timeliness of rewards and punishments, etc., on procrastination (Milgram \& Tenne, 2000; Steel, 2007). In our opinion, such a division is relative, because external conditions are always assessed through the subject's individual characteristics and states, so the connection is more complex and indirect.

Milgram spoke about four types of procrastination: life routine procrastination, which manifests itself in putting off routine responsibilities; decisional procrastination; compulsive procrastination, which combines decisional procrastination with putting off doing tasks; and academic procrastination (Milgram \& Tenne, 2000). 
Currently most studies of procrastination are about learning activity, due to both the unquestionable significance of this topic for improving the educational process, as well as the greater availability of subjects for research (students). The results obtained from student samples became a major contribution to understanding procrastination, but this issue is significant not only for the educational, but also for the professional environment, which sets high requirements for personal effectiveness, mediated by the need to keep up with changes, to meet deadlines ("time is money"), to have irregular working hours, to excel in a highly competitive environment, and so on (Barabanshchikova \& Marusanova, 2016; Ivanenko, 2012; Sypkova, 2011). It should not be overlooked that procrastination not only prevents the professional's self-actualization, but it also has a negative impact on organizations' work, under the enormous pressure of market economy conditions.

Of great interest are the studies conducted on various samples of professionals, including virtual project team members (Barabanshhikova \& Kaminskaja, 2013), professional athletes (Barabanshchikova, Ostanina, \& Klimova, 2015), as well as in organizations of various types, including innovative ones (Barabanshchikova, 2016; Barabanshchikova \& Ivanova, 2016; Barabanshchikova \& Ivanova, 2017).

The main goal of the present study is to identify and analyze the impact of personal, professional, and organizational factors on the procrastination of employees of a modern Russian industrial organization.

On the level of the single personality, we studied as the possible procrastination predictors the most common behavior patterns in professional situations in three aspects: communications, task management, and self-management (Bartram, Brown, Fleck, Inceoglu, \& Ward, 2006).

On the level of the professional, we studied the subjective perception of various aspects of the work environment, occupational stress syndrome, and persistent professional deformation (Leonova, 2004).

In our study we use the following definition of procrastination: Procrastination is a systematic delay in performing urgent and important tasks or making decisions, which are perceived as such, accompanied by a complex of negative emotions and obviously leading to a worsening of the situation or the result (Kovylin, 2013; Milgram et al., 1992).

During the preparation of the study we posed the following general conjectures:

1. The level of procrastination among employees of the enterprise we studied defines the typical behavior patterns in performing professional tasks, the subjective appraisal of job difficulties, the experience of stress and its consequences, and perception of the organizational culture.

2. There are significant personal, professional, and organizational predictors of procrastination in modern professionals.

\section{Study Design}

Participants in the study were 120 employees of a Russian industrial enterprise that produces electric buses. The study involved engineers and office workers, including design engineers, process engineers, production managers, supply service employees, quality service employees, etc. The sample included 70 women and 50 men, 20 
to 63 years of age (mean age 35 years), work experience in this company 1 to 431 months (mean work experience 51 months).

The study procedure included computerized testing and individual feedback upon the results; the data were analyzed with IBM SPSS Statistics v. 22.

We used the following diagnostic methods:

1. The Tuckman General Procrastination Scale, adapted by T.L. Kryukova, was used to define the level of procrastination (Krjukova, 2009). This questionnaire contains 35 statements that the subject has to agree or disagree with. There are 25 direct and 10 reverse questions. This method makes it possible to assess the subject's general level of procrastination.

2. The OPQ 32 Questionnaire by SHL Group was used to assess typical behavior patterns in the work environment during performance of professional tasks (Bartram et al., 2006). The result of this method is a profile that includes a score on 33 scales divided into three main blocks: communications, task management, and self-management.

3. The Managerial Stress Survey (MSS) by A.B. Leonova was used to obtain overall characteristics of occupational stress syndrome, from the psychological reasons for its development to robust forms of personal and behavioral disadaptation (Leonova, 2006).

4. The Organization Paradigms Inventory (OPI) by L. Constantine was used to assess specific characteristics of the organizational culture of the industrial enterprise (Lipatov, 2005).

\section{Results}

All the employees were divided into three groups, based on their level of procrastination as shown by the results of the study:

The first group: employees whose subjective assessment of their level of procrastination is in the range of 1 to 4 stens and who do not consider themselves to be prone to delaying important and urgent matters "for later". This group included 25 people, or $21 \%$ of the subject sample.

The second group: employees whose level of procrastination lies in the high range (7-10 stens) and who admit to having pronounced symptoms of procrastination. This group included 42 people, or $35 \%$ of the subject sample.

The third group: employees whose level of procrastination is in the medium range and whose habit of delaying important tasks and decisions "for later" is not chronic, but rather occurs occasionally. This group included 53 people, or $44 \%$ of the subject sample.

The first and second groups are especially interesting for our study. In order to understand the specific characteristics of the group data, we created profiles that reflect the four main aspects that we studied: typical behavior patterns of a specialist in occupational situations, subjective appraisal of job difficulties, aspects of occupational stress syndrome, and evaluations of the company's organizational culture. The four resulting profiles are presented below as histograms, the first column of which is the mean score of the first group and the second column is the mean score of the second group. 


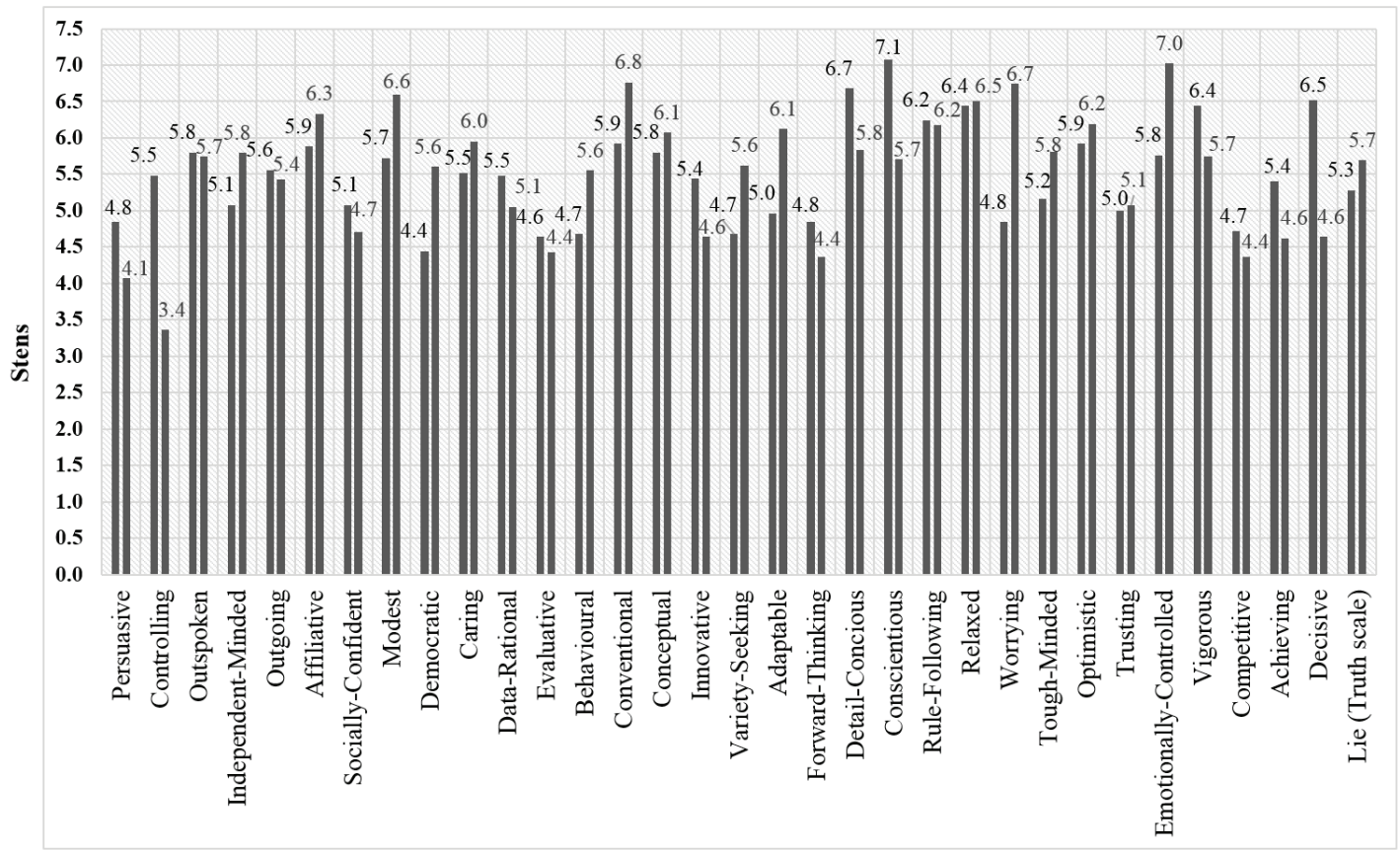

Scales of the OPQ 32 Questionnaire by SHL Group

Figure 1. Mean profiles of typical behavior patterns in occupational situations (OPQ 32 Questionnaire) for groups of employees with different levels of procrastination.
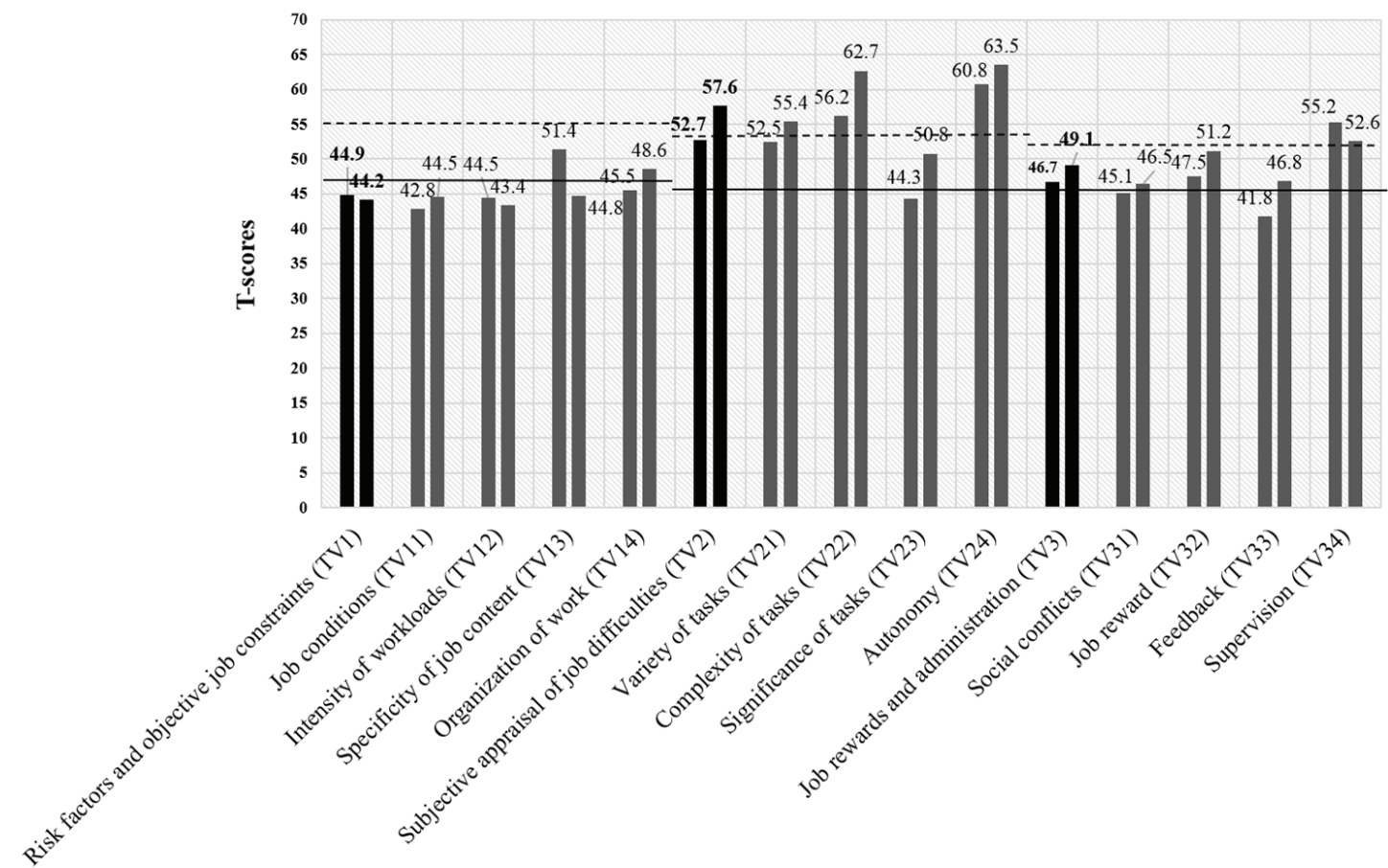

Scales of the Managerial Stress Survey (MSS) by A.B. Leonova (TV1-TV3)

Figure 2. Perception of the occupational environment (MSS) in groups with different procrastination levels: pronounced symptoms, - - - high scores. 
Analyzing the resulting profile (Figure 1), it can be suggested that the majority of assessed characteristics (typical behavior patterns in an occupational situation) - the scores on 25 of 33 scales - are in the range of medium scores $(5,6$ stens), which are insufficient to identify the specific characteristics of the studied groups. We focus on analyzing the scales, the mean scores of which are either on the lower or higher end of the scale. The employees from a group with a high level of procrastination present such characteristics as greater emotional control, worrying, conventionality, and modesty; low scores were obtained for them on the scale for control. The group with low procrastination is detail-conscious, conscientious, and decisive.

Figure 2 shows the perception of various aspects of the occupational environment in two employee groups, from the perspective of their influence on the development of occupational stress syndrome. The group with a high procrastination level demonstrates dissatisfaction with such aspects of their occupational activity as its organizational characteristics, high variety, the complexity and significance of professional tasks, insufficient independence during the work process, and excessive control by management. Employees with a low procrastination level, on the other hand, are dissatisfied with the content of their work, the high variety and complexity of their professional tasks, and a lack of independence and excessive control.

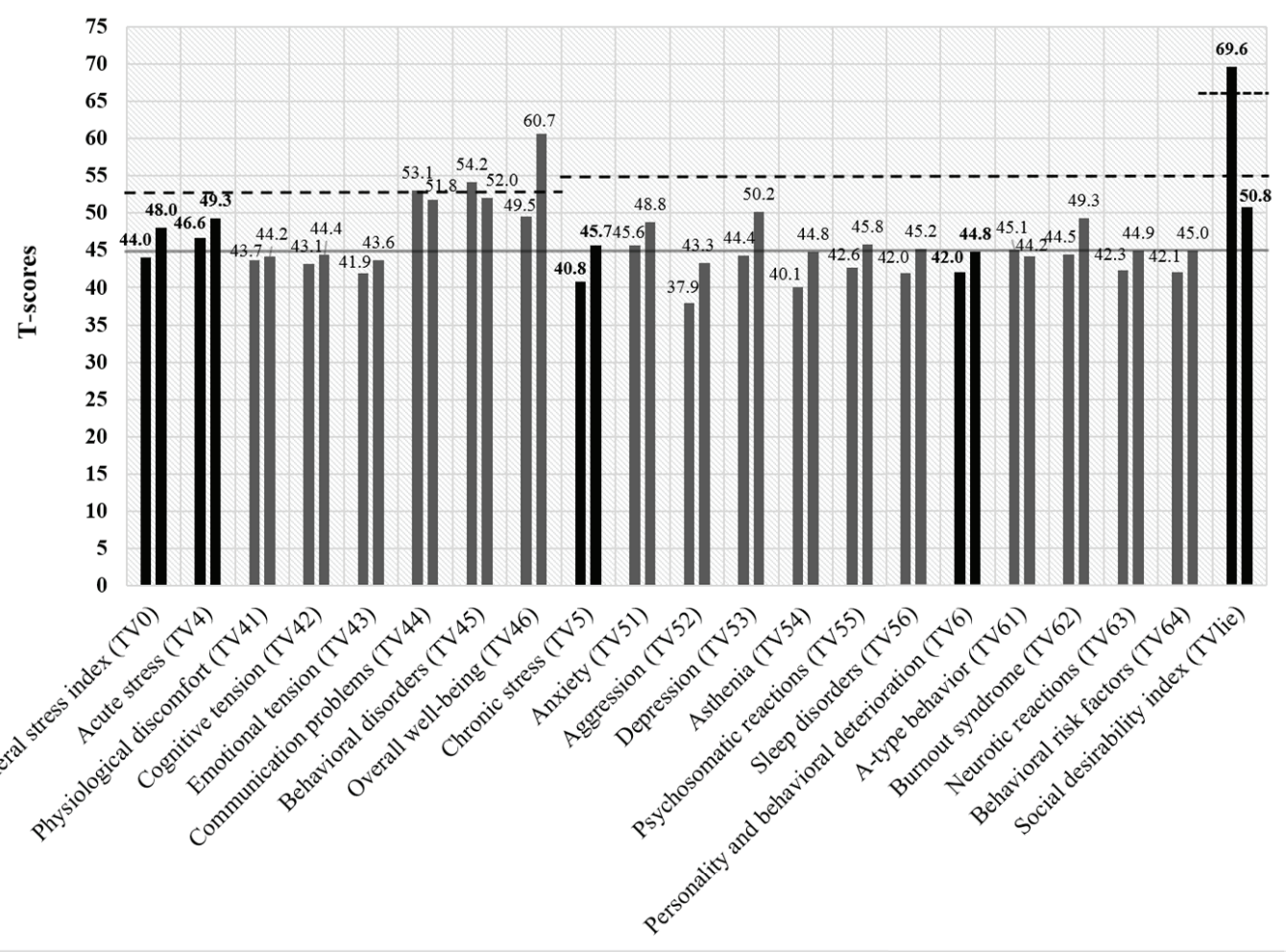

Scales of the Managerial Stress Survey (MSS) by A.B. Leonova (TV0, TV4-TV6, TVlie)

Figure 3. Characteristics of acute and chronic stress and the consequences of experiencing stress (MSS) in groups with different levels of procrastination: pronounced symptoms, - - - - high scores, - - - extremely high scores. 
Figure 3, reflecting the specific aspects of acute and chronic stress, as well as the consequences of experiencing them, shows that the group with high procrastination is much more prone to occupational stress. This group has high acute and chronic stress, high anxiety, depression, and psychosomatic reactions, along with a number of persistent negative consequences, such as signs of emotional burnout syndrome, neurotic reactions, and behavioral risk factors. The group with low procrastination also has some of the symptoms of acute stress, but the chronic forms and persistent deformations are much less often expressed. It is worth noticing the social desirability of the answers, which reaches extremely high scores in the group with low procrastination, meaning that we have to account for this scale when analyzing the results. It shows the desire of this subject group to guess the expectations of their social milieu and to sugarcoat their image and the real state of affairs in the eyes of others.
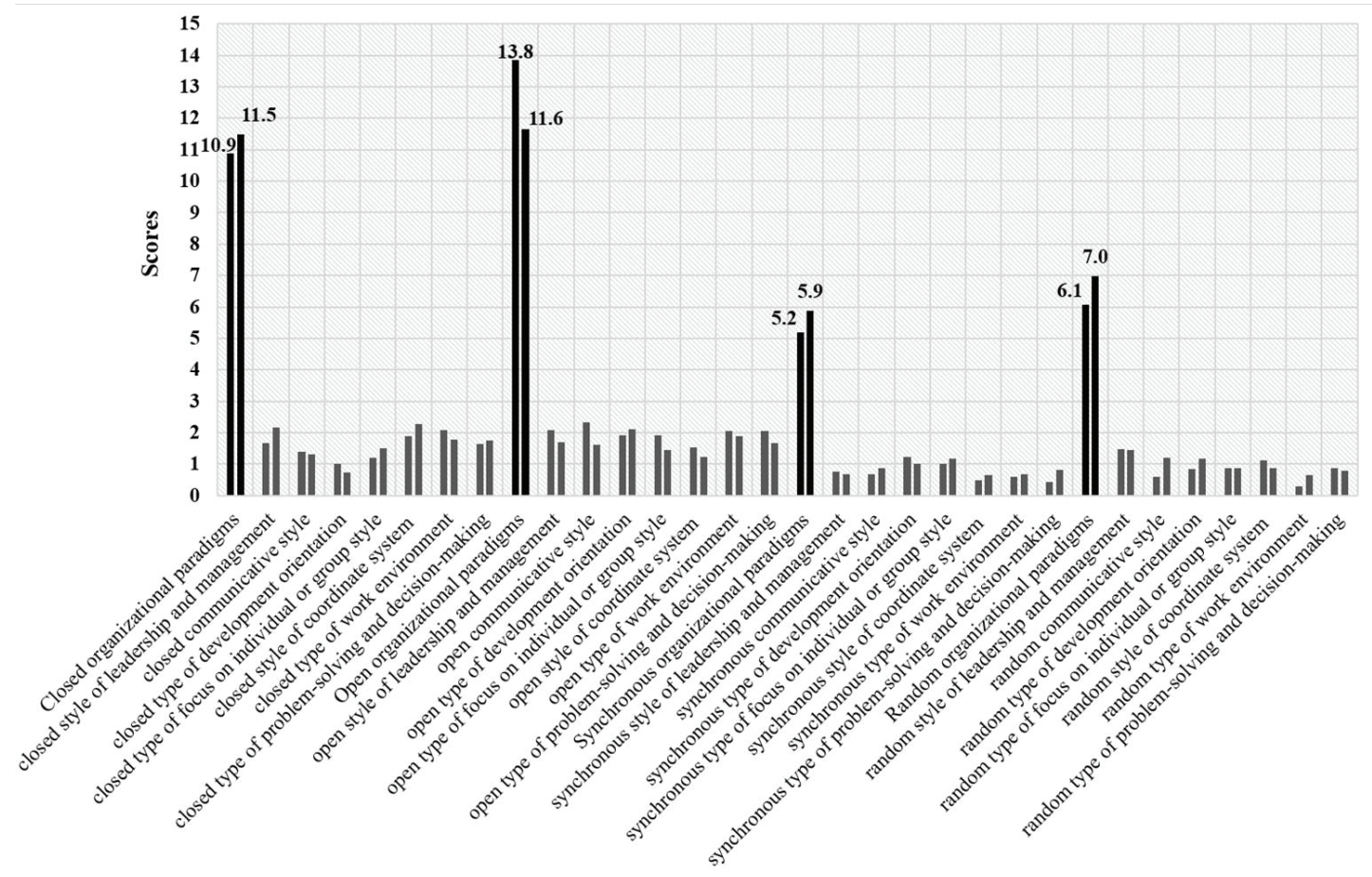

Scales of the Organization Paradigms Inventory (OPI) by L. Constantine

Figure 4. Perception of organizational culture (OPI) in groups with different levels of procrastination.

Analyzing the employees' perception of their industrial enterprise's organizational culture (Figure 4), it can be suggested that representatives from both groups agree that the main aspects of their organization's activity are of the open or closed types of organizational paradigms. For a more detailed analysis of the perception of organizational characteristics, it is necessary to identify group differences in the evaluation of their affiliation with the proposed models.

In order to assess group differences for employees with high and low procrastination scores, we compared the mean scores of two independent samples with Stu- 
dent's t-test, identifying a number of differences that highlight the groups' specific aspects (Table 1).

Table 1

Comparison of Two Employee Groups with High and Low Procrastination Scores (Student's t-test).

\begin{tabular}{|c|c|c|c|c|c|c|}
\hline \multirow{2}{*}{ Variable scales } & \multicolumn{2}{|c|}{$\begin{array}{c}\text { Group } 1 \\
(\mathrm{~N}=25)\end{array}$} & \multicolumn{2}{|c|}{$\begin{array}{c}\text { Group } 2 \\
(\mathrm{~N}=42)\end{array}$} & \multirow{2}{*}{$\begin{array}{c}\text { Student } \\
\text { t-test }\end{array}$} & \multirow{2}{*}{$\mathbf{p}$} \\
\hline & $\mathbf{M}$ & SD & $\mathbf{M}$ & SD & & \\
\hline Controlling & 5.5 & 2.3 & 3.4 & 2.1 & 3.887 & 0.000 \\
\hline Democratic & 4.4 & 1.4 & 5.6 & 2.1 & -2.430 & 0.018 \\
\hline Variety-seeking & 4.7 & 1.6 & 5.6 & 1.7 & -2.201 & 0.031 \\
\hline Adaptable & 5.0 & 1.5 & 6.1 & 2.1 & -2.401 & 0.019 \\
\hline Conscientious & 7.1 & 1.9 & 5.7 & 1.9 & 2.788 & 0.007 \\
\hline Worrying & 4.8 & 2.0 & 6.7 & 2.3 & -3.466 & 0.001 \\
\hline Emotionally controlled & 5.8 & 2.0 & 7.0 & 2.1 & -2.448 & 0.017 \\
\hline Decisive & 6.5 & 1.3 & 4.6 & 2.1 & 4.004 & 0.000 \\
\hline Work content (TV13) & 51.4 & 9.8 & 44.8 & 9.9 & 2.657 & 0.010 \\
\hline Subjective appraisal of job difficulties (TV2) & 52.7 & 7.5 & 57.6 & 6.9 & -2.752 & 0.008 \\
\hline Complexity of tasks (TV22) & 56.2 & 9.5 & 62.7 & 10.8 & -2.477 & 0.016 \\
\hline Significance of tasks (TV23) & 44.3 & 7.9 & 50.8 & 7.5 & -3.357 & 0.001 \\
\hline General stress index (TV0) & 44.0 & 4.0 & 48.0 & 3.8 & -4.082 & 0.000 \\
\hline Acute stress (TV4) & 46.6 & 3.4 & 49.3 & 4.0 & -2.751 & 0.008 \\
\hline Overall well-being (TV46) & 49.5 & 9.4 & 60.7 & 11.0 & -4.240 & 0.000 \\
\hline Chronic stress (TV5) & 40.8 & 3.5 & 45.7 & 4.6 & -4.601 & 0.000 \\
\hline Aggression (TV52) & 37.9 & 4.8 & 43.3 & 7.1 & -3.318 & 0.001 \\
\hline Depression (TV53) & 44.4 & 3.2 & 50.2 & 6.5 & -4.166 & 0.000 \\
\hline Asthenia (TV54) & 40.1 & 2.9 & 44.8 & 5.2 & -4.177 & 0.000 \\
\hline Psychosomatic reactions (TV55) & 42.6 & 4.3 & 45.8 & 5.0 & -2.658 & 0.010 \\
\hline Sleep disorders (TV56) & 42.0 & 3.2 & 45.2 & 5.0 & -2.912 & 0.005 \\
\hline Burnout syndrome (TV62) & 44.5 & 4.8 & 49.3 & 7.1 & -3.043 & 0.003 \\
\hline Behavioral risk factors (TV64) & 42.1 & 4.6 & 45.0 & 6.2 & -2.011 & 0.048 \\
\hline Social desirability index (TVlie) & 69.6 & 13.8 & 50.8 & 11.6 & 5.975 & 0.000 \\
\hline Open communicative style & 2.3 & 1.1 & 1.6 & 1.1 & 2.612 & 0.011 \\
\hline Random communicative style & 0.6 & 0.8 & 1.2 & 0.9 & -2.764 & 0.007 \\
\hline
\end{tabular}

Note. $M=$ mean, $S D=$ standard deviation. 
Thus, in the block of variables describing typical behavior patterns in occupational environments, the most significant $(\mathrm{p}<0.001)$ were the differences in such characteristics as control (the urge to take responsibility, to control the work situation and the people there), worrying, and decisiveness. Slightly less significant $(\mathrm{p}<0.05)$ were the group differences concerning democracy, variety seeking, adaptability, conscientiousness, and emotional control.

Analyzing the mean scores for the abovementioned scales in the two groups, we found that in the group with a high level of procrastination, the employees are less prone to seek control of the surrounding situation, taking responsibility for other people and tasks; they worry more, are prone to postponing decisions, but they also have high scores for emotional control, which reflects the tendency to hide their true emotions from their colleagues. On the other hand, among the employees from the group with low procrastination scores, we observed relatively high decisiveness, high conscientiousness, but lower variety-seeking scores, as well as lower scores on the democracy scale, which points to a tendency to make decisions unilaterally.

The group differences in the occupational environment assessment mainly concern such characteristics as work content, subjective appraisal of job difficulties, and the complexity and significance of occupational tasks. The group with a high level of procrastination assesses professional tasks as highly significant and highly complex, and a negative evaluation of the occupational situation generally prevails. In the group with a low level of procrastination, concern with task significance is less pronounced, tasks are considered more routine; on the other hand, work content and the professional situation in general have significantly negative scores.

Group differences were found for many characteristics of acute and chronic stress syndrome and the consequences of experiencing them. The group with a high level of procrastination showed a significantly high level of occupational stress in its acute and chronic types. This group also has high and pronounced signs of the consequences of stress, in the form of various personal and behavioral deformations, whereas the group with a low level of procrastination presents only minor symptoms of acute stress, without its transformation into the chronic type and the consequences thereof. The second group demonstrates such deformations as aggression, depression, asthenia, psychosomatic reactions, decline of overall wellbeing, sleep disorders, signs of burnout syndrome, and behavioral risk factors.

Describing the group differences in perception of organizational culture, we can point out that representatives of the group with a low level of procrastination note the signs of an open-type culture in their organization, along with expressed, active, even sometimes excessive communications among employees. Representatives of the group with a high level of procrastination concentrate on random, nonsystemic, and uncontrolled information exchange in the organization.

Thus, the results of the comparison allow us to accept the possibility of dividing the groups on the basis of the level of procrastinations of their representatives, while obtaining a multi-aspect picture of the special characteristics of each group.

Although this analysis reveals certain specific characteristics of "procrastinators", it does not allow us to define which of the parameters described above might be procrastination predictors and which should draw special attention and be corrected, in order to lower the possibility of their occurrence and to lower the procrastination tendencies in professional activity. 
Table 2

Correlations Between Level of Procrastination and Four Groups of Characteristics

\begin{tabular}{|c|c|c|}
\hline Variable scales & $\mathbf{R}$ & $\mathbf{p}$ \\
\hline General stress index (TV0) & 0.427 & 0.000 \\
\hline Cognitive tension (TV42) & 0.194 & 0.034 \\
\hline Emotional tension (TV43) & 0.266 & 0.003 \\
\hline Overall well-being (TV46) & 0.398 & 0,000 \\
\hline Anxiety (TV51) & 0.252 & 0.005 \\
\hline Aggression (TV52) & 0.412 & 0.000 \\
\hline Depression (TV53) & 0.382 & 0.000 \\
\hline Asthenia (TV54) & 0.427 & 0.000 \\
\hline Psychosomatic reactions (TV55) & 0.200 & 0.029 \\
\hline Sleep disorders (TV56) & 0.259 & 0.004 \\
\hline Personal and behavioral disadaptation (TV6) & 0.235 & 0.010 \\
\hline Burnout syndrome (TV62) & 0.374 & 0.000 \\
\hline Neurotic reactions (TV63) & 0.193 & 0.035 \\
\hline Work content (TV13) & -0.323 & 0.000 \\
\hline Variety of tasks (TV21) & 0.188 & 0.039 \\
\hline Complexity of tasks (TV22) & 0.243 & 0.008 \\
\hline Significance (TV23) & 0.328 & 0.000 \\
\hline Job remuneration and administration (TV3) & 0.242 & 0.008 \\
\hline Job compensation/remuneration (TV32) & 0.209 & 0.022 \\
\hline Controlling & -0.290 & 0.001 \\
\hline Innovative & -0.185 & 0.043 \\
\hline Adaptable & 0.220 & 0.016 \\
\hline Detail-conscious & -0.188 & 0.039 \\
\hline Conscientious & -0.357 & 0.000 \\
\hline Decisive & -0.358 & 0.000 \\
\hline Random type of communication & 0.237 & 0.009 \\
\hline Random type of work environment & 0.207 & 0.023 \\
\hline Open organizational paradigm & -0.222 & 0.015 \\
\hline Open style of leadership and management & -0.156 & 0.090 \\
\hline Open communicative style & -0.251 & 0.006 \\
\hline Open focus on individual or group style & -0.194 & 0.034 \\
\hline Open problem-solving and decision-making & -0.173 & 0.059 \\
\hline Social desirability index (TVlie) & -0.539 & 0.000 \\
\hline
\end{tabular}

Note. $R=$ Pearson correlation coefficient. 
For this task we created a regression model, which allows us to define the main predictors of procrastination in the employees of the enterprise.

We assigned the level of procrastination as a dependent variable.

The selection of independent variables for the regression model was based on the results of correlation analysis of the relation between level of procrastinations and the four groups of characteristics described above (typical behavior patterns in occupational situations, occupational stress syndrome and its consequences, perception of organizational culture). It was also extended by a number of characteristics, which in our view might have a significant impact on procrastination (Table 2).

Thus, the regression model includes the following characteristic groups as independent variables:

1. Typical behavior patterns in the occupational environment, including: control, independent-mindedness, outgoingness, group affiliation, tendency to evaluate, innovativeness, adaptability, detail-consciousness, conscientiousness, and decisiveness.

2. Subjective perception of the occupational environment: occupational content (TV13), variety of tasks (TV21), complexity of tasks (TV22), significance of tasks (TV23), job remuneration and administration (TV3), and job compensation/remuneration (TV32).

3. Characteristics of occupational stress syndrome and its consequences: general stress index (TV10), cognitive tension (TV42), emotional tension (TV43), overall well-being (TV46), anxiety (TV51), aggression (TV52), depression (TV53), asthenia (TV54), psychosomatic reactions (TV55), sleep disorders (TV56), personal and behavioral deformation (TV6), signs of burnout syndrome (TV62), and neurotic reactions (TV63).

4. Perception of organizational culture: random type of organizational culture, random type of leadership and management, random type of communication, random type of development orientation, random type of focus on individual or group style, random style of coordinate system, random type of work environment, random type of problem-solving and decisionmaking, open organizational paradigm, open style of leadership and management, open communicative style, open type of development orientation, open type of focus on individual or group style, open style of coordinate system, open type of work environment, open type of problem-solving and decision-making.

5. Social desirability index and the scale of coherence.

Table 3

Statistical Parameters of the Regression Model

\begin{tabular}{cccc}
\hline $\mathbf{R}$ & $\mathbf{R}^{2}$ & Adjusted $^{2}$ & $\mathbf{p}$ \\
\hline 0.853 & 0.728 & 0.569 & 0.000 \\
\hline
\end{tabular}

Note. $R=$ Pearson correlation coefficient; $R^{2}=$ regression coefficient . 
As a result of the analysis we obtained a regression model, the statistical parameters of which are presented in Table 3.

Based on the obtained regression model, we can state that the chosen variables influence the level of procrastination among employees and explain 56.9\% of the variance of the studied variable - the level of procrastination.

The most significant variables are presented in Table 4.

Table 4

Significance of the Regression Model's Components

\begin{tabular}{lc}
\hline \multicolumn{1}{c}{ Variable scales } & p \\
\hline \multicolumn{1}{c}{ Outgoingness } & 0.040 \\
Innovative & 0.005 \\
Detail-consciousness & 0.017 \\
Conscientiousness & 0.030 \\
Work content (TV13) & 0.023 \\
Significance of tasks (TV23) & 0.020 \\
Anxiety (TV51) & 0.000 \\
Depression (TV53) & 0.048 \\
Open type of development orientation & 0.037 \\
Social desirability index (TVlie) & 0.014 \\
\hline
\end{tabular}

Thus, the most significant characteristics in predicting the level of procrastination are outgoingness (the urge to be the center of attention and, in the most severe cases, excessive talkativeness), innovative thinking, detail-consciousness, and conscientiousness. Other significant factors include work content and significance of tasks. Moreover, significant contributions to the model's predictive value are the robust consequences of occupational stress syndrome, such as anxiety and depression, along with aspects of organizational culture such as the open type of development orientation and the social desirability of responses.

\section{Discussion and Conclusions}

The results allowed us to identify specific characteristics of professionals who have a high level of procrastination and who acknowledge their tendency to delay important and urgent tasks and decisions "for later", in comparison with employees who deny that they have such symptoms. In the procrastinators group, the prevailing characteristics of behavior in occupational situations are a low level of control (i.e., a lack of desire to control the work situation), unwillingness to take extra responsibility, less decisiveness, high anxiety, and emotional control, which manifests itself in avoidance of real emotional expression during work. The interrelationship of these personal features with the level of procrastination is confirmed by a number of studies (Kovylin, 2013; Steel, 2007; Varvaricheva, 2013). It is worth noting that none of the aforementioned characteristics were included in the regression 
model; these characteristics might be the consequences and not the predictors of procrastination. In other words, people who consciously put off urgent matters "for later" experiences anxiety and a number of negative emotions that they try to hide; this is accompanied by avoidance of unnecessary responsibility and a decrease in decisiveness on a wide range of professional questions. This result is confirmed by a number of studies that show the relationship between procrastination and a tendency for an avoidance-oriented coping strategy, manifested in a person's desire to escape from a stressful situation (Bykova, 2013; Kornilova, 2013; Krjukova, 2010). Furthermore, our study identified the following characteristics as procrastination predictors: low conscientiousness; high outgoingness, which manifests itself in excessive sociability; high innovativeness, which is characterized by an increased interest in creative tasks and avoidance of executive tasks; and increased interest in variability, which manifests itself in an urge to frequently change one's activity and a negative attitude towards routine matters.

Additional significant procrastination predictors are work content and high significance of the tasks performed, which can lead to a kind of closed loop, whereby people who are constantly under the pressure of high responsibility for their work attempt to ease this pressure by putting off the most "pressing" matters for later, thereby only increasing the urgency of the situation.

This is probably why the procrastinators group has more pronounced symptoms of occupational stress syndrome, particularly the chronic type, along with persistent personal and behavioral deformations. The question of whether the stress is the cause or the consequence of the procrastination tendency remains controversial (Kovylin, 2013). At the same time, the relationship between procrastination and stress has been confirmed by recent studies (Barabanshchikova \& Ivanova 2017; Barabanshhikova \& Kaminskaja, 2013; Barabanshchikova et al., 2015). The regression model we obtained allows us to define at least two consequences of stress, namely anxiety and depression, which are the significant procrastination predictors. Hence, people who remain under the influence of stressful factors for a long time and who discover symptoms of anxiety and depression in themselves are more prone to put off complex and important tasks and decisions.

It is worth noting such components of the regression model as the social desirability index, which is one of the most significant procrastination predictors. In the present study, we found a negative correlation between the social desirability index and the level of procrastination, which demonstrates the wish of some of the participants (particularly those from the low-procrastination group) to sugarcoat their image in the eyes of others.

In conclusion, our study established that characteristics related to procrastination can have different types of correlations. Some of them are reasons and predictors that make it possible to predict the level of procrastination; some accompany procrastination, being its consequences or side effects. Furthermore, while studying the possible reasons for procrastination in the occupational environment, it is necessary to proceed at different levels of analysis - from personal and behavioral characteristics to organizational components of the occupational environment. This approach makes possible a systematic description of risk factors for procrastination and will help to find appropriate methods to stop its negative impact on a professional's life and on the effectiveness of the company's work. 


\section{References}

Barabanshchikova, V.V. (2016). Professional'nye deformatsii v professiyakh innovatsionnoy sfery: Dis. ... d-ra psikhol. nauk. [Professional deformations in innovative professions]. Moscow [in Russian].

Barabanshchikova, V.V., \& Ivanova, S.A. (2016). Vliyanie organizatsionno-lichnostnykh faktorov na uroven' vyrazhennosti prokrastinatsii u sotrudnikov sovremennoy organizatsii [The impact of organizational and personal factors on the level of procrastination in employees of a modern organization]. Eksperimental'naya psikhologiya [Experimental Psychology], 9(1), 95-111 [in Russian].

Barabanshchikova, V.V., \& Ivanova, S.A. (2017). Prediktory prokrastinatsii v trudovoy deyatel'nosti sovremennogo professionala [Predictors of procrastination in the modern employee's work activity]. Psikhologicheskiy zhurnal [Psychological Journal], 38(3), 44-56 [in Russian].

Barabanshchikova, V.V., \& Kaminskaya, E.O. (2013). Fenomen prokrastinatsii v deyatel'nosti chlenov virtual'nykh proektnykh grupp [The phenomenon of procrastination in virtual project team members]. Natsionalnyy psikhologicheskiy zhurnal [National Psychological Journal], 2(10), 43-51 [in Russian].

Barabanshchikova, V.V., \& Marusanova, G.I. (2016). Perspektivy issledovaniya fenomena prokrastinatsii v professional'noy deyatel'nosti [Prospects of studying the phenomenon of procrastination in professional activity]. Natsional'nyy psikhologicheskiy zhurnal [National Psychological Journal], no. 1, 130-140 [in Russian].

Barabanshchikova V.V., Ostanina M.V., \& Klimova O.A. (2015). Fenomen prokrastinatsii v deyatel'nosti sportsmenov individual'nykh i komandnykh vidov sporta [The phenomenon of procrastination in the activities of athletes of individual and team sports]. Natsional'nyy psikhologicheskiy zhurnal [National Psychological Journal], 19(3), 91-104 [in Russian].

Bartram, D., Brown, A., Fleck, S., Inceoglu, I., \& Ward, K. (2006). Technical manual: OPQ32. UK: SHL Group plc.

Burka, J.B., \& Yuen, L.M. (2008). Procrastination: Why you do it, what to do about it (2nd ed.). Boston: Da Capo Press.

Bykova, D.V. (2013). Prokrastinatsiya kak proyavlenie emotsional'no-orientirovannogo i orientirovannogo na izbeganie stiley kopinga [Procrastination as a manifestation of emotionallyoriented and avoidance-oriented coping styles]. Psikhologiya stressa i sovladayushchego povedeniya: materialy III Mezhdunar. nauchno-prakticheskoy konferentsii. [Psychology of stress and coping behavior: Proceedings of the Third International Scientific-Practical Conference], vol. 1. Kostroma: KGU im. N.A. Nekrasova, 194-196 [in Russian].

Dementiy, L.I., \& Karlovskaya, N.N. (2013). Osobennosti otvetstvennosti i vremennoy perspektivy u studentov s raznym urovnem prokrastinatsii [Specific aspects of responsibility and temporary challenges for students with various levels of procrastination]. Psikhologiya obucheniya [Psychology of Education], 7, 4-19 [in Russian].

Ferrari, J.R., \& Emmons, R.A. (1995). Methods of procrastination and their relation to selfcontrol and self-reinforcement. Journal of Social Behavior and Personality, 10, 455-458.

Ferrari, J.R., Johnson, J.L., \& McCown, W.G. (1995). Procrastination and task avoidance: Theory, research, and treatment. New York: Plenum Press. https://doi.org/10.1007/978-1-48990227-6

Garanyan, N.G., Andrusenko, D.A., \& Khlomov, I.D. (2009). Perfektsionizm kak faktor studencheskoy dezadaptatsii [Perfectionism as a factor of student disadaptation]. Psikhologicheskaya nauka i obrazovanie [Psychological Science and Education], 1, 72-81 [in Russian]. 
Ivanenko, K. (2012). Prokrastinatsiya - eto zlo [Procrastination is evil]. Sluzhba kadrov i personal [Personnel department and staff], 6, 43-48 [in Russian].

Karlovskaya, N.N. (2008). Vzaimosvyaz' obshchey i akademicheskoy prokrastinatsii i trevozhnosti u studentov s raznoy akademicheskoy uspevaemost'yu [The interconnection of general and academic procrastination and anxiety in students with different degrees of academic progress]. Psikhologiya v vuze [Psychology at the University], 3, 38-49 [in Russian].

Kornilova, T.V. (2013). Mel'burnskiy oprosnik prinyatiya resheniy: russkoyazychnaya adaptatsiya [Melbourne decision-making questionnaire: A Russian adaptation]. Psikhologicheskie issledovaniya [Psychological Studies], 6(31), 4 [in Russian].

Kovylin, V.S. (2013). Teoreticheskie osnovy izucheniya fenomena prokrastinatsii [Theoretical bases of the phenomenon of procrastination]. Lichnost'v menyayushchemsya mire: zdorov'e, adaptatsiya, razvitie [Personality in a changing world: health, adaptation, development], 2(2), 22-41 [in Russian].

Kryukova, T.L. (2009). Stili sovladayushchego povedeniya v trudnykh zhiznennykh situatsiyakh [Coping strategies in difficult life situations]. In V.A. Bodrov \& A.L. Zhuravlev (Eds.), Aktual'nye problemy psikhologii truda, inzhenernoy psikhologii i ergonomiki [Contemporary problems of the psychology of work, engineering psychology and ergonomics]. Moscow: Izdatel'stvo Institut psikhologii RAN.

Kryukova, T.L. (2010). Stili sovladayushchego povedeniya v trudnykh zhiznennykh situatsiyakh [Coping strategies in difficult life situations]. Zhurnal prakticheskogo psikhologa [Journal of the Applied Psychologist], 2, 3-22 [in Russian].

Kuper, K.L., \& Marshall, Dzh. (1995). Istochniki stressa "belykh vorotnichkov" [Sources of stress among "white collar" workers]. In A.B. Leonova \& O.N. Chernysheva (Eds.), Psikhologiya truda i organizatsionnaya psikhologiya: sovremennoe sostoyanie i perspektivy razvitiya. Khrestomatiya. [Psychology of work and organizational psychology: current state and prospects of development. Anthology.] Moscow: Radiks.

Leonova, A.B. (2004). Kompleksnaya strategiya analiza stressa: ot diagnostiki k profilaktike i korrektsii [A comprehensive strategy analysis of occupational stress: From diagnosis to prevention and correction]. Psikhologicheskiy zhurnal [Psychological Journal] 25(2), 75-85 [in Russian].

Leonova, A.B. (2007). Metodika integral'noy diagnostiki i korrektsii professional'nogo stressa (IDIKS): metodicheskoe rukovodstvo [Managerial Stress Survey (MSS): Procedure manual]. St. Petersburg: IMATON [in Russian].

Lipatov, S.A. (2005). Oprosnik "Shkaly organizatsionnykh paradigm" L.L. Konstantina [L.L. Constantine's "Scales of Organizational Paradigms" questionnaire]. Zhurnal prakticheskogo psikhologa [Journal of the Applied Psychologist], 2, 186-198 [in Russian].

Milgram, N., Gehrman, T., \& Keinan, G. (1992). Procrastination and emotional upset: A typological model. Personality and individual differences, 1, 1307-1313. https://doi. org/10.1016/0191-8869(92)90173-M

Milgram, N., \& Tenne, R. (2000). Personality correlates of decisional and task avoidant procrastination. European Journal of Personality, 14, 141-156. https://doi.org/10.1002/(SICI)10990984(200003/04)14:2<141::AID-PER369>3.0.CO;2-V

Mokhova, S.B., \& Nevryueev, A.N. (2013). Psikhologicheskie korrelyaty obshchey i akademicheskoy prokrastinatsii u studentov [Psychological correlates of communication and students' academic procrastination]. Voprosy psikhologii [Issues of Psychology], 1, 24-35 [in Russian].

Shemyakina, O.O. (2013). Vliyanie prokrastinatsii na uroven' stressa u studentov [The impact of procrastination on the stress levels of students]. Psikhologiya i pravo [Psychology and Law], 4, [in Russian]. 
Steel, P. (2007). The nature of procrastination: A meta-analytic and theoretical review of quintessential self-regulatory failure. Psychological Bulletin, 133(1), 65-94. https://doi. org/10.1037/0033-2909.133.1.65

Sypkova, S. (2011). Prokrastinatsiya - chuma belykh vorotnichkov [Procrastination - a plague of white-collar workers]. Sluzhba kadrov i personal [Personnel Department and Staff], 4, 48-50 [in Russian].

Tarasevich, G. (2014). Prokrastinatsiya: bolezn' veka [Procrastination: The disease of the century]. Russkiy reporter [Russian Reporter], 14(342), 20-29 [in Russian].

Varvaricheva, Ya.I. (2013). Fenomen prokrastinatsii: problemy i perspektivy issledovaniya [The phenomenon of procrastination: Problems and prospects of research]. Voprosy psikhologii [Issues of Psychology], 3, 121-131 [in Russian].

Vindeker, O.S., \& Ostanina, M.V. (2014). Formal'nyy i soderzhatel'nyy analiz shkaly obshchey prokrastinatsii C.H. Lay (na primere studentcheskoy vyborki) [A formal and comprehensive analysis of C.H. Lay's General Procrastination Scale (on an example of student sampling)]. Aktual'nye problemy psikhologicheskogo znaniya: teoreticheskie i prakticheskie problemy psikhologii [Contemporary Problems of Psychological Science: Theoretical and Practical Problems of Psychology, 1(30), 116-126 [in Russian].

Zvereva, M.V. (2015). Adaptatsiya oprosnika PASS na rossiyskoy vyborke [Adaptation of the PASS Questionnaire to a Russian sample]. Psikhologicheskaya nauka i obrazovanie [Psychological Science and Education], 20(1), 79-84 [in Russian].

Zvereva, M.V., Enikolopov, S.N., \& Oleychik, I.V. (2015). Prokrastinatsiya i agressiya pri psikhicheskoy patologii u lits molodogo vozrasta [Procrastination and aggression as mental disorders in young people]. Psikhologicheskaya nauka i obrazovanie [Psychological Science and Education], 20(2), 70-77 [in Russian]. 